\title{
Determining the Dimension of Liveability of Malaysian Affordable Housing
}

\author{
Wilson Rangga Anthony Jiram, Azizah Ismail, Fatin Aziz
}

\begin{abstract}
There is intense concern about the liveability aspect of the affordable housing schemes in the Malaysia context. Thus, this paper provides a qualitative evaluation to determine the affordable housing liveability dimensions. This was accomplished by conducting the focus group discussion with a sample of 11 participants consisting of experts from government bodies, public and private universities and non-government organisations. A content analysis was used to determine the dimensions of affordable housing liveability. The analyses revealed that, affordable housing liveability is conceptualized as a composite of seven dimensions such as physical aspects, community and neighbourhood, public amenities, economic development, residence wellbeing, safety and security, and psychology impact. The findings will be useful to policymakers, urban planners, and developers to undertake a more active role in providing better quality of affordable housing.
\end{abstract}

Keywords: liveability, affordable housing, affordability.

\section{INTRODUCTION}

$\mathrm{H}$ ousing forms one of the basic needs of human; Maslow's Theory Hierarchy of Needs describes that housing forms the foremost important need [1]. Oberlink (2008) specifies housing is such a fundamental necessity that people often question about where to live largely on the basis of what kind of housing options are available and whether these options meet their current budget and requirement ${ }^{2}$. Hence housing is a major concern for all people in every corner of the world as the wellbeing of a country is reflected in its people enjoying a certain standard of living.

Most governments throughout the world strive to come up with solutions to solve housing woes by developing affordable housing as fast as possible. For instance, in Malaysia, the government through the 10th Malaysia Plan (10MP), had targeted 78,000 units of affordable houses to be built, consisting of 38,950 units under the People's Housing Programme (PHP) and 39,050 units under programmes related to the Ministry of Rural and Regional Development to meet the needs of the low- income groups and squatters. Although the National Housing Policy (NHP) Malaysia 2013 does emphasise on essentials such as quality construction and provision of public amenities, there is fear that in trying to meet such targeted affordable housing numbers, the

Revised Manuscript Received on October15, 2019

* Correspondence Author

Wilson Rangga Anthony Jiram*, Department of Real Estate, Universiti Teknologi Malaysia, Johor Bahru, Malaysia. Email: rangga@utm.my

Azizah Ismail, Department of Real Estate, Universiti Teknologi Malaysia, Johor Bahru, Malaysia. Email: azizahismail@utm.my

Fatin Aziz, Centre of Studies for Estate Management, Universiti Teknologi MARA, Shah Alam, Malaysia. Email: fatinaziz@uitm.edu.my liveability aspect can be compromised. This is especially so in light of high land and building construction cost [22].

There is often confusion among people about the term "affordable housing", and "livable home". Affordable housing is housing unit for those with median household income, which provides a wide range of needs for low and middle-income households and the affordability of affordable housing and can cover their basic cost of living [3]. Affordable housing is generally defined as a housing that can be provided at a reasonable cost i.e., at an affordable price and not more than 30 percent of the gross household income for the low to medium income group [28,29,30,31].

Tan (2012) stated that most of the public low-cost housing schemes that were launched by the government over the past 20 years have failed to improve the quality of life of their residents ${ }^{4}$. In fact, many housing areas developed under these schemes have turned into slums that do not provide a wholesome environment for families. Low-cost housing is priced between RM35, 000 and RM42, 000, therefore, many of these units are small whereby the built-up area is approximately 650 square feet. As a result, children tend to spend their time in corridors, on fire-escape landings or in the car parks, due to lack of space and privacy [4].

In general, affordable housing is designed to meet the needs of medium and low-income households where they have inadequate income to access appropriate housing in the market without the assistance programmes and other essential basic living costs. In the U.S., broad characteristics of 'affordable housing' are that it is privately owned, socially oriented, and price restricted [5]. Affordable housing is also shelter, which cost no more than $30 \%$ of one's total income (The Canada Mortgage \& Housing Corporation, 2008).Thus, the 'affordable housing' term describes housing that assists lower income households in obtaining and paying for suitable housing without suffering undue financing hardship [6]. Norazmawati (2007) stated that 'affordable housing concept pertains to the amount of income needed to pay for the house and other household expenditures. It is also defined as a house that can be obtained without serious financing risks which has been set by most countries worldwide as 30 percent income limit.'[7]

The government defined the low-income group as B40 and middle income as group M40 in Malaysia. Such definition was timely specially to assist the defined population in terms of housing. Furthermore, such definition did reflect the growing concerns to address issues faced by the M40 group. B40 group households earn below RM3,860 a month have always been given attention by the government, through leadership programs and economic enhancement programmes.

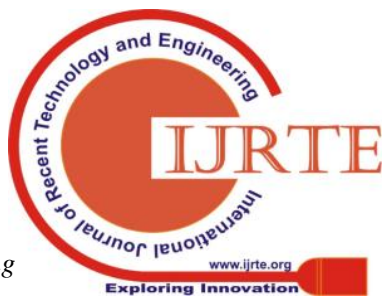


This group is entitled for low cost housing schemes. M40 group refers to the category of 40 per cent of Malaysia's middle-income group. The government through Budget 2016 had set targets for this group in light of rising costs and housing

Table- I: Liveability attributes

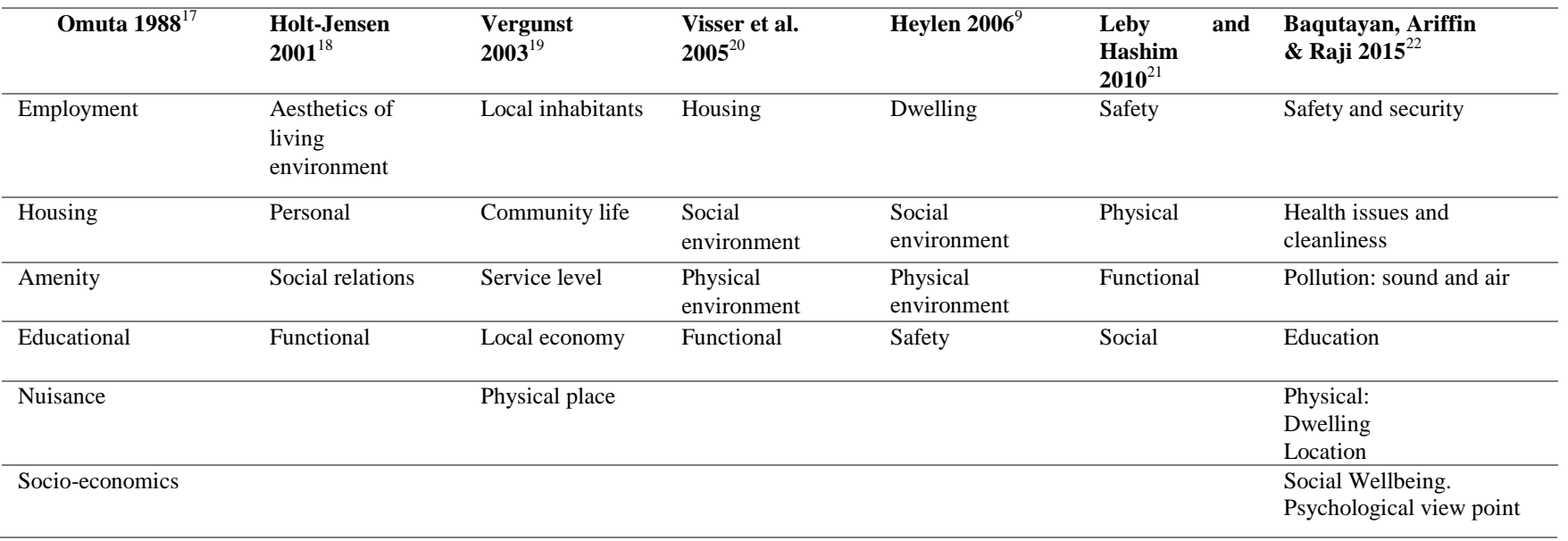

Household income for the M40 group is in the range of RM3,860 to RM8,319 a month, although seeming sufficient but burdened with the high cost of living, especially in urban areas, is inadequate or simply insufficient to sustain life in the city. These groups of consumers fall in the middle-income trap with regards to housing adequacy. Generally, this group of consumers would fall within the affordable housing category.

Concept of liveability is difficult to define and evaluate $[8,9,10,11]$. It is a relative term of which the actual meaning depends on the place, time and purpose of the assessment, and on the value system of the assessor [12]. Research has linked the concept of liveability to a range of factors such as quality of life, health, sense of safety, access to services, cost of living, comfortable living standards, mobility and transport, air quality and social participation $[13,14]$. Liveability also defined as 'quality of life' as experienced by the residents within a city or region [15]. Liveability refers also to a built-up system that contributes to the physical, social and mental well-being as well as personal development of all its inhabitants. It is about delightful and desirable spaces that offer and reflect cultural and sacred enrichment [15]. Liveability refers to the subgroup of sustainability impacts that directly affect people in a community, such as economic development, affordability, public health, social equity and pollution exposure [16].

Table- II: Affordable Housing Perimeters

\begin{tabular}{lllll} 
Income & Category & $\begin{array}{l}\text { Dwelling } \\
\text { size } \\
\text { (sq. ft) }\end{array}$ & $\begin{array}{l}\text { Dwelling } \\
\text { Price } \\
\text { (RM) }\end{array}$ & $\begin{array}{l}\text { Minimum } \\
\text { Accommodation }\end{array}$ \\
\hline $\begin{array}{l}\text { RM3,860 } \\
\text { to }\end{array}$ & M 40 & $700-1000$ & 150,000 to & $\begin{array}{l}\text { 3 bedrooms, dining } \\
\text { area, drying area }\end{array}$ \\
RM8,319 & & & 400,000 & $\begin{array}{l}\text { and a minimum of } \\
\text { separate bathroom } \\
\text { per month }\end{array}$ \\
+- & & & & and toilet.
\end{tabular}

Based on Malaysian standards, affordable housing in terms of physical dwelling size ranges from $600 \mathrm{sq} f t$ to $1200 \mathrm{sq} \mathrm{ft}$. Since the existing policy for low cost housing insists that all dwellings must have provision of three bedrooms with addition of dining area, drying area as well as a separate bathroom and toilet, this minimum should follow through for affordable housing. In setting up the perimeters for this research, several factors of cognizance were considered namely the M40 group income level; the purposed built affordable housing schemes and the minimum requirement for low cost housing. Hence the criteria for affordable housing in this research should fall within the perimeters in Table II.

\section{RESEARCH METHODOLOGY}

\section{A. Preliminary Consideration of Research Paradigm}

The purpose of this study is to explore government bodies, Public and Private Universities, and NGOs views with the intent of using this information to determine the affordable housing liveability dimension and attributes. This qualitative method study utilised within the interpretivist paradigm [23] This research undertook an inductive research approach to drawing conclusions from the qualitative data. This was accomplished by collecting the focus group data to provide a full picture of the extent of coverage of affordable housing liveability dimension. 11 experts consisting of government bodies, Public and Private Universities, and NGOs took part in the study (see Table III). Participants were recruited through purposive sampling [24].

Table- III.Participants of the FGD

\begin{tabular}{lll}
\hline No. & Organization & Specialised area \\
\hline 1 & The Congress of Unions of & Management Team \\
& $\begin{array}{l}\text { Employees in the Public and Civil } \\
\text { Services Malaysia (CUEPACS) }\end{array}$ \\
\hline 2 & The Congress of Unions of & Board Member \\
& $\begin{array}{l}\text { Employees in the Public and Civil } \\
\text { Services Malaysia (CUEPACS) }\end{array}$ \\
\hline 3 & Iskandar Regional Development & Management Team \\
& Authority (IRDA) & \\
\hline 4 & The Royal Malaysia Police & $\begin{array}{l}\text { Department of Crime } \\
\text { (PDRM) }\end{array}$ \\
& & $\begin{array}{l}\text { Prevention and Community } \\
\end{array}$
\end{tabular}




\begin{tabular}{lll}
\hline No. & Organization & Specialised area \\
\hline 5 & Kuala Lumpur City Hall (DBKL) & $\begin{array}{l}\text { Economic Planning and } \\
\text { Development Department }\end{array}$ \\
\hline 6 & Kuala Lumpur City Hall (DBKL) & City Planning Department \\
\hline 7 & Kuala Lumpur City Hall (DBKL) & City Planning Department \\
\hline 8 & Sepang Municipal Council & $\begin{array}{l}\text { Town Planning \& Landscape } \\
\text { Department }\end{array}$ \\
\hline 9 & Universiti Selangor (UNISEL) & Environmental scientist \\
\hline 10 & $\begin{array}{l}\text { Universiti Teknologi Malaysia, } \\
\text { Kuala Lumpur }\end{array}$ & Psychologist \\
\hline 11 & $\begin{array}{l}\text { Universiti Teknologi Malaysia, } \\
\text { Kuala Lumpur }\end{array}$ & Real estate \\
& & \\
\hline
\end{tabular}

\section{B. Focus Group Rationale}

In this research, FGD was held to explore the liveability of affordable housing dimensions. To develop measuring instruments for this research, questions in the FGD were converted into themes that corresponds with the research objective $^{25}$. The purpose of the FGD was to establish the content validity of the conceptual framework. Participants have the assurance that their real names will be replaced by their pseudonyms if quoted in the research results.

\section{Data Analysis}

The analysis served to answer the researh question answering question concerning the dimensions of affordable housing liveability. Content analysis were used to determine the dimensions [26] of affordable housing liveability. A total of 11 participants were interviewed, which were transcribed and for coding. Codes concisely describe the condensed meaning unit and are tools to help researchers reflect on the data. The next step was to develop codes that are descriptive labels for the condensed meaning units. The next step was to sort codes into categories by comparing codes and appraising them to determine which codes seem to belong together, thereby forming a category and analysis were carried on creating themes. The researchers have continued the process of abstracting data to a higher level, from category to theme level, and developed three themes as well as an overarching theme. Themes express underlying meaning, i.e., latent content, and are formed by grouping two or more categories together.

\section{FINDINGS}

The focus group interview was conducted to determine the affordable housing liveability dimension through the analysis of the views of an expert consisting of government bodies, Public and Private Universities, and NGOs. Table 4 shows the summary of expert view on focus group protocol. The protocol focused specifically on evaluating the affordable housing liveability dimension.

Table- IV: Construct and indicator of Affordable Housing Liveability

\begin{tabular}{lll}
\hline No. & Construct & Indicator \\
\hline 1 & Physical Aspects & \\
\hline & & Accommodation \\
\hline & Size \\
\hline & Parking Facilities \\
\hline & Recreation Facilities \\
\hline & Multi-purpose hall \\
\hline & Surau/Faith room
\end{tabular}

\begin{tabular}{|c|c|c|}
\hline No. & Construct & Indicator \\
\hline & & Lift Facilities \\
\hline & & Connectivity (Internet and television) \\
\hline \multirow[t]{4}{*}{2} & $\begin{array}{l}\text { Community \& } \\
\text { Neighborhood Factors }\end{array}$ & \\
\hline & & Trustworthy Neighbors \\
\hline & & Helpful Neighbors \\
\hline & & Neighborhood Associations \\
\hline \multirow[t]{19}{*}{3} & Public Amenities & \\
\hline & & Childcare \\
\hline & & Pre-school \\
\hline & & School \\
\hline & & Bus \\
\hline & & MRT/LRT/Train \\
\hline & & Taxi Service \\
\hline & & Recreation \\
\hline & & Clinic \\
\hline & & Hospital \\
\hline & & Shopping facilities \\
\hline & & Grocery \\
\hline & & Supermarket \\
\hline & & Wet market \\
\hline & & Farmers' market \\
\hline & & Mosque \\
\hline & & Libraries \\
\hline & & Launderette \\
\hline & & Post-office \\
\hline \multirow[t]{5}{*}{4} & Economic Development & \\
\hline & & Distance to Place of Work \\
\hline & & House Price / Rental \\
\hline & & Proximity to Commercial Area \\
\hline & & Proximity to Industrial Zone \\
\hline \multirow[t]{5}{*}{5} & Residence Wellbeing & \\
\hline & & Children Development \\
\hline & & Domestic Violence \\
\hline & & Cleanliness \\
\hline & & Pollution \\
\hline \multirow[t]{6}{*}{6} & Safety \& Security & \\
\hline & & Crime \\
\hline & & Fire Management \\
\hline & & Police Station \\
\hline & & Security Guardsispe? \\
\hline & & Safe Walking At Night \\
\hline \multirow[t]{5}{*}{7} & Psychological Impact & \\
\hline & & Feeling of Safety \\
\hline & & Acceptance of Existing Dwelling \\
\hline & & Social-wellbeing \\
\hline & & Emotional Wellbeing \\
\hline
\end{tabular}

The analyses signified that, affordable housing liveability is conceptualized as a composite of seven at such as physical aspects, community and neighbourhood, public amenities, economic development, residence wellbeing, safety and security, and psychology impact. Liveability has been associated and linked with sustainability by many researchers $[16,21,27]$. Previous studies revealed many indicators, dimensions and attributes of measuring or achieving livability depending on the focus or focuses. Basically livable houses are dwellings that improve the quality of life of all occupants at all stages of their life and must be easy to enter; navigate in and around; capable of easy and cost-effective adaptation; and responsive to the changing needs of occupants [15]. Livable housing is a place that is safe, attractive, socially cohesive and inclusive, and environmentally; with affordable housing in linked to employment, education, public spaces, shops, health services, recreation and cultural prospects; via public transport, walking and cycling infrastructure [27].

\section{CONCLUSION}


Result has determined 7 constructs and 45 indicators for affordable housing liveability dimension. Affordable housing liveability dimension comprises of physical aspects, community and neighbourhood, public amenities, economic development, residence wellbeing, safety and security, and psychology impact. It is important to continue to test the affordable housing liveability dimensions, so that additional reliability evidence and construct validity can be achieved. Hence, it is hoped that this paper will encourage positive debate and gain some attention from the policymakers, practitioners and researchers in Malaysia. Public policy makers and local authorities should undertake a more active role in providing better quality of affordable housing through utilisation of town planning tools such as development plans, development control, and planning decision.

\section{ACKNOWLEDGMENT}

The work is supported by the Research Management Centre of Universiti Teknologi Malaysia (UTM) and the Ministry of Higher Education (Malaysia) under the Research University Grant (GUP) Vot. 17J18, and Fundamental Research Grant Scheme (FRGS) respectively.

\section{REFERENCES}

1. Maslow A.H. (1943) Theory of Human Motivation, Psychological Review. 50: 370- 396. Australia

2. Oberlink,, M.R. (2008). Opportunities for Creating Livable Communities. AARP Public Policy Institute. Washington, DC: AARP.

3. Milligan, V., Phibbs, P., Gurran, N., \& Fagan, K. (2007). Approaches to Evaluation of Affordable Housing Initiatives in Australia. National Research Venture 3: Housing Affordability for Lower Income Australians, Research Paper No. 7.

4. Tan T. H. (2012). Locational, Neighbourhood, Structural and Social-Cultural Attributs of Housing in Homeownership Decisions. Proceeding for 6th International Real Estate Research Symposium (IRERS 2012). 24 - 25 April.

5. Anderson, L. M., Charles, J. S., Fullilove, M. T., Scrimshaw, S. C., Fielding, J. E., Normand, J., \& Task Force on Community Preventive Services. (2003). Providing affordable family housing and reducing residential segregation by income: a systematic review. American journal of preventive medicine, 24(3), 47-67.

6. Milligan, V., Phibbs, P., Fagan, K., \& Gurran, N. (2004). A practical framework for expanding affordable housing services in Australia: learning from experience.

7. Norazmawati, M. S. (2007). Kemampuan pemilikan rumah kos rendah di Kuala Lumpur. A PhD Thesis submitted to the Universiti Sains Malaysia, Penang, Malaysia.(Translation: Affordability of a low-cost house in Kuala Lumpur).

8. Balsas, C. J. (2004). City centre regeneration in the context of the 2001 European Capital of Culture in Porto, Portugal. Local economy, 19(4), 396-410.

9. Heylen, K. (2006). Liveability in social housing: Three case studies in Flanders. In ENHR Conference'Housing in an Expanding Europe: Theory, Policy, Implementation and Participation', Date: 2006/07/02-2006/07/05, Location: Ljubljana (Slovenia).

10. Throsby, D. (2005). Cultural heritage as financial asset in strategies for urban development and poverty alleviation. Paper for International Conference for Integrating Urban Knowledge \& Practice, Gothenburg, Sweden, 29 May-3 June, 2005.

11. Wheeler, S.M. (2001). Livable communities: Creating safe and livable neighborhoods, towns and regions in California (Working Paper
2001-2004). Berkeley: Institute of Urban and Regional Development, University of California.

12. Pacione, M. (2003). Urban environmental quality and human wellbeing - a social geographical perspective. Landscape and urban planning, 65(1), 19-30.

13. Bishop, B. J., \& Syme, G. J. (1995). The social costs and benefits of urban consolidation: A time budget/contingent valuation approach. Journal of economic psychology, 16(2), 223-245.

14. Howley, P., Scott, M., \& Redmond, D. (2009). An examination of residential preferences for less sustainable housing: Exploring future mobility among Dublin central city residents. Cities, 26(1), 1-8.

15. Timmer, V., \& Seymoar, N. K. (2005, March). Vancouver Working Group Discussion Paper. In The World Urban Forum 2006.

16. Litman, T. (2011). Sustainability and Liveability: Summary of Definitions, Goals, Objectives and Performance Indicators. Monograph Victoria Transport Policy Institute.

17. Omuta, G. E. (1988). The quality of urban life and the perception of liveability: A case study of neighbourhoods in Benin City, Nigeria. Social Indicators Research, 20(4), 417-440.

18. Holt-Jensen, A. (2001, June). Individual relational space in deprived urban neighbourhoods. In ENHR conference (Vol. 25, p. 29).

19. Vergunst, P. (2003). Liveability and ecological land use. PhD diss., Swedish University of Agricultural Sciences.

20. Visser, P., van Dam, F. and Hooimeijer, P. (2005). The influence of neighbourhood characteristics on geographical differences in house prices in the Netherlands. Paper presented at European Network for Housing Research (ENHR) International Housing Conference, 29 June-3 July 2005, Reykjavik, Iceland.

21. Leby, J. L., \& Hashim, A. H. (2010). Liveability dimensions and attributes: Their relative importance in the eyes of neighbourhood residents. Journal of Construction in Developing Countries, 15(1), 67-91.

22. Baqutayan S., Ariffin A. \& Raji F. (2015). Describing The Need For Affordable Livable Sustainable Housing Based On Maslow's Theory of Need. Mediterranean Journal of Social Sciences, Vol 6 (3).

23. Denzin, N. K., \& Lincoln, Y. S. (Eds.). (2011). The Sage handbook of qualitative research. Sage.

24. Creswell , J. (2012). Qualitative Inquiry and Research Design: Choosing Among Five Approaches. SAGE Publications

25. Boeije, H. (2010) Analysis in Qualitative Research. Sage Publications, London, UK (2010).

26. Creswell , J. (2012). Qualitative Inquiry and Research Design: Choosing Among Five Approaches. SAGE Publications

27. Lowe, M., Whitzman, C., Badland, H., Davern, M., Aye, L., Hes, D., Butterworth, I. and Giles-Corti, B., 2015. Planning healthy, liveable and sustainable cities: How can indicators inform policy?. Urban Policy and Research, 33(2), pp.131-144.

28. Ismail, I., Bujang, A. A., Jiram, W. R. A., Zarin, H. A., \& Rahman, M. S. A. (2018). Sarawak Bumiputera's Housing Affordability: A Preliminary Investigation. Advanced Science Letters, 24(6), 4299-4303.

29. Jiram, W. R. A., Bujang, A. A., Zarin, H. A., \& Anuar, F. H. M. (2016, March). Empirical evaluation of Gen Y housing affordability. In Knowledge, Service, Tourism \& Hospitality: Proceedings of the Annual International Conference on Management and Technology in Knowledge, Service, Tourism \& Hospitality 2015 (SERVE 2015), Bandung, Indonesia, 1-2 August 2015 (p. 155). CRC Press.

30. Ismail, A., Bujang, A. A., Jaafar, M. N., Jiram, W. R. A., Zarin, H. A., \& Maimun, N. H. A. (2018). Household's housing affordability stress in iskandar malaysia: a review. Advanced Science Letters, 24(6), 4295-4298.

31. Shapee, N. A. S., Bujang, A. A., Jaafar, M. N., Jiram, W. R. A., \& Zarin, H. A. (2018). Household's Economic Wellbeing in Homeownership Affordability: A Review. Advanced Science Letters, 24(6), 4290-4294 


\section{AUTHORS PROFILE}

Wilson Rangga Anthony Jiram is a Senior Lecturer at Universiti Teknologi Malaysia. His research interests lie in the real property of Malaysia, particularly property market, economics, and property surveying competencies. Currently writing and carrying out research on housing liveability, affordability, and socio-economic wellbeing.

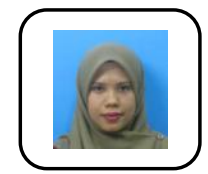

Azizah Ismail is a Senior Lecturer at Universiti Teknologi Malaysia. Her research interests lie in the housing economic and affordability.

Fatin Aziz is a Lecturer at Universiti Teknologi MARA, Shah Alam. Her research interests lie in the property market research. 